University of Nebraska - Lincoln

DigitalCommons@University of Nebraska - Lincoln

Management Department Faculty Publications

Management Department

$12-1969$

Evidence on the Validity of Management Education

Fred Luthans

James W. Walker

Richard M. Hodgetts

Follow this and additional works at: https://digitalcommons.unl.edu/managementfacpub

Part of the Business Administration, Management, and Operations Commons, Management Sciences and Quantitative Methods Commons, and the Strategic Management Policy Commons

This Article is brought to you for free and open access by the Management Department at

DigitalCommons@University of Nebraska - Lincoln. It has been accepted for inclusion in Management Department Faculty Publications by an authorized administrator of DigitalCommons@University of Nebraska - Lincoln. 


\title{
Evidence on the Validity of Management Education
}

\author{
FRED LUTHANS \\ University of Nebraska \\ JAMES W. WALKER \\ International University \\ RICHARD M. HODGETTS \\ University of Nebroska
}

The authors feel that more attention should be given to the empirical validation of management education. In order to determine what effect a college degree and the academic major have on promotability, 3,202 marketing personnel of a major petroleum corporation were analyzed.

What effect does a college education have on executive success? Does the major area of study make any difference? Does any kind of management education or development yield tangible returns to an employing organization? In other words, have management formal education and development been empirically validated? Many organizations are seriously beginning to ask these questions. The current body of management knowledge has not given a satisfactory answer. For instance, in the latest edition of Koontz and O'Donnell's management text the authors observe, "At this stage of our knowledge, it must be confessed that no one really knows .... There are many instances where managers credit improvement in their skill to their training, but it is really not possible to generalize these views." 1 In Albers' latest edition, he also indicates there is little, if any, objective validation of broadly defined management education and development. He states that,

Some formal training undoubtedly improves executive performance and reduces the time required for adaptation to present and potential positions. It can be carried to an extreme. There is little

${ }^{1}$ Harold Koontz and Cyril O'Donnell, Principles of Management, 4th ed. (New York: McGraw-Hill, 1968), p. 530. 
in the way of objective measures to indicate exactly what is gained by various kinds of programs. ${ }^{2}$

Despite the apparent lack of knowledge of the tangible effects, there is a marked upsurge in the reliance on and use of all types of management education and development. Titles of recent articles in business periodicals point to this upsurge. An article in Fortune depicted the almost fanatical emphasis given to "The M.B.A.-The Man, the Myth, and the Method."'3 Also, Dun's Review aptly titled a recent article "There's No Business Like Seminar Business" (Sept., 1967, p. 36). Every type of organization, including military, hospital, university, and business, is attempting to hire college graduates, sending present personnel back to study for master's degrees, and is making extensive use of in-house and/or outside programs for management development. This wide ranging educational experience extends from first line supervision to the apex of the hierarchical structure. The formal higher educational experience comes almost completely from colleges and universities. 4 The shorter, developmental programs may be administered by the organizations' headquarters, individual organizational units, or outside organizations such as universities or associations. The American Management Association alone makes most of its $\$ 10$ million annual income from 1,500 seminar meetings. In total, an estimated 18,000 trade associations and consultants and more than 2,000 private and public educational institutions run business seminars. ${ }^{5}$

The logical point of departure in validating the various methods of educating and developing managers would seem to be the college educational experience itself. The generally held assumption is that the university is the major source of raw talent for management. Is this assumption justified? If it is, what type of education is the most appropriate? This study was designed to provide data to help answer these two questions and thus move toward validating management education.

\section{METHOD OF RESEARCH}

Extensive data were collected from the entire marketing department $\{3,615$ individuals $)$ of a major petroleum corporation. A total of 413 persons were removed from the tabulation because of incomplete information. Therefore, the total sample represents 3,202 persons employed at all levels and functions of marketing in one large corporation. Types of jobs included

${ }^{2}$ Henry H. Albers, Principles of Management: A Modern Approach, 3d ed. (New York: John Wiley and Sons, 1969), p. 676.

"Sheidon Zalaznick, "The M.B.A.-The Man, the Myth, and the Method," Fortune (May, 1968), p. 168.

'Some large corporations such as the General Motors Institute and G.E.'s Institute at Croton-on-the-Hudson have entered into types of formal higher education. The military has also been quite involved in maintaining their own formal educational schooling. However, both still rely primarily on colleges and universities for educating their personnel.

"There's No Business Like Seminar Business," Dun's Review (Sept., 1967), p. 36. 
field marketing representatives, district managers, staff specialists, and higher-level marketing managers and executives.

The purpose of the research study was to validate the effects that college education in general and academic majors in particular had on job success in this company. As in any validation study, an outside criterion for success had to be determined. The single success criterion used in this study was a promotability rating given by the man's immediate superior. This rating was also reviewed by the next level manager in each case. Data on each person's formal higher educational background were then analyzed according to his current promotability rating.

\section{RESULTS OF THE ANALYSIS}

\section{Formal Educational Background}

The 3,202 marketing personnel were initially categorized into promotable and nonpromotable groups. A total of 2,260 persons were rated as promotable and 942 were rated as nonpromotable. Table 1 shows these two groups according to their formal educational background. The table clearly indicates that those considered as promotable are better educated than those felt to be nonpromotable. The large majority (75 per cent) of nonpromotables have either not attended college at all or have not received a baccalaureate degree. On the other hand, practically all (84 per cent) of those personnel considered eligible for advancement in the company have attended college and most (59 per cent) have received their degree.

TABLE 1

Formal Higher Education of Promotable and Nonpromotable Marketing Personnel

\begin{tabular}{lrrrrr}
\hline Education & \multicolumn{2}{c}{ Promotables } & \multicolumn{2}{c}{ Nonpromotables } \\
& No. & $\%$ & No. & $\%$ \\
\hline No College Work & 370 & 16 & 394 & 42 \\
Some College Work & 546 & 25 & 308 & 33 \\
Baccalaureate Degree & 1,260 & 55 & 223 & 23 \\
Master's or Law Degree & 77 & 4 & 16 & 2 \\
Doctorate & 7 & 0 & 1 & 0 \\
\hline Total & 2,260 & 100 & 942 & 100 \\
\hline
\end{tabular}

These initial results are generally in accord with past research which indicates an increasing percentage of business and industrial managers have a college education. The Warner and Abegglen study found that executives in 1952 were better educated than their counterparts of 1928. Fifty-seven per cent of the 1952 group possessed college degrees and another 19 per cent had attended college. ${ }^{6}$ A 1959 survey of 562 managers from a number of industrial classifications found 61 per cent of top man-

${ }^{\circ} \mathrm{W}$. Lloyd Warner and James C. Abegglen, Occupational Mobility in American Business and Industry, 1928-1952 (Minneapolis: University of Minnesota Press, 1955) and Big Business Leaders in America (New York: Harper and Brothers, 1955). 
agement, 63 per cent of middle managers, and 62 per cent of the lower level managers were college graduates. ${ }^{7}$ Half the total personnel in this current study had college degrees and three-fourths had some college work. The slight decrease in college graduates can probably be best explained by the characteristics of this marketing department sample. However, for the purposes of this study, the most important finding is the significantly higher educational levels of the promotables over the nonpromotables in this sample. Thus, at first glance formal education does seem to correlate with executive success.

A more detailed analysis of the data revealed that this relationship between education and promotability is not simple. Table 2 shows the promotable group reclassified into various degrees of promotability-promotable immediately (within six months), promotable within two years,

\section{TABLE 2}

The Formal Higher Education of Marketing

Personnel According to Varying Degrees of Promotability

\begin{tabular}{|c|c|c|c|c|c|c|}
\hline \multirow[t]{2}{*}{ Education } & \multicolumn{2}{|c|}{$\begin{array}{l}\text { Promotab/e } \\
\text { Immediately }\end{array}$} & \multicolumn{2}{|c|}{$\begin{array}{c}\text { Promotable } \\
\text { Within Two } \\
\text { Years }\end{array}$} & \multicolumn{2}{|c|}{$\begin{array}{c}\text { Promotable } \\
\text { Within } \\
\text { Two to } \\
\text { Five Years }\end{array}$} \\
\hline & No. & $\%$ & No. & $\%$ & No. & $\%$ \\
\hline $\begin{array}{l}\text { No College Work } \\
\text { Some College Work } \\
\text { Baccalaureate Degree } \\
\text { Master's or Law Degree } \\
\text { Doctorate }\end{array}$ & $\begin{array}{r}166 \\
191 \\
356 \\
18 \\
1\end{array}$ & $\begin{array}{r}22.7 \\
26.1 \\
48.6 \\
2.5 \\
.1\end{array}$ & $\begin{array}{r}114 \\
225 \\
612 \\
46 \\
5\end{array}$ & $\begin{array}{r}11.4 \\
22.4 \\
61.0 \\
4.6 \\
.6\end{array}$ & $\begin{array}{r}90 \\
30 \\
292 \\
13 \\
1\end{array}$ & $\begin{array}{r}17.1 \\
24.7 \\
55.5 \\
2.5 \\
.2\end{array}$ \\
\hline Total & 732 & 100.0 & 1,002 & 100.0 & 426 & 100.0 \\
\hline
\end{tabular}

and promotable within two to five years. This classification indicates that those considered to be potentially promotable (within two years and two to five years) had more formal education than those managers rated immediately promotable. This finding can be best explained by examining some of the differing personal characteristics between the immediately promotable group and the potentially promotable group. The employees in the potentially promotable group were younger, had less time on their current jobs and with the company, were in lower level jobs, made less money, and, probably most important, had a much lower performance rating than did the immediately promotable group. This overall profile of the potentially promotables suggests that their biggest assets are youth and education. The fact that they were rated as potentially promotable indicates their youth and educational background may override the relatively poor performance record (the potentially promotable individuals actually had a poorer performance rating than did those considered nonpromotable).

'Frank C. Pierson et al., The Education of American Businessmen (New York: McGrawHill, 1959), p. 102. 
On the other hand, the immediately promotable group was still relatively young (average age of 41 which was 10 years younger than the nonpromotables) and had a comparatively good education. The immediately promotables also had the best performance records and had been with the company a relatively long time (15 years). Therefore, the analysis indicates that age and education may initially overcome poor performance, as in the case of the potentially promotables, but when the actual promotion decision is immediately forthcoming, performance may be the deciding factor. The point to be made is that there is no simple cause and effect relationship between education and executive success. Nevertheless, in general, formal education does seem to play an important but complex role in management success.

\section{Type of Educational Background}

If one assumes that a college education is a necessary prerequisite in management, then the next logical question becomes what kind of education? Almost every educator and practitioner has a ready answer to this question. On the one hand, there are those who advocate a broad liberal arts education as the best type of preparation for executive work. ${ }^{8}$ Because of this reasoning, much criticism has been leveled against the business schools for emphasizing vocationalism and high degrees of specialized training. ${ }^{9}$ Although the business community is generally espousing the concept of a broad liberal education through speechmaking and editorializing, they are clamoring at the placement offices for highly trained specialists in engineering, accounting, finance, marketing, personnel, and production. The relatively higher starting salaries for these specialized graduates is indicative of this demand.

Who is right? What type of formal education will be most beneficial for executive success? Once again the body of knowledge does not give an adequate answer. This study tried to answer this question by determining the educational major of each college graduate in the sample $(\mathrm{N}=$ 1,534). Again using promotability rating as the criterion of success, Table 3 shows the results. A ranking of No. 1 meant promotable immediately, No. 2 indicated promotable within two years, No. 3 was assigned to those promotable within two to five years, and No. 4 was given to those who were judged by their superiors to be nonpromotable. Therefore, the mean ratings shown in Table 3 have an inverse relationship with promotability. At first glance the Life and Earth Science group, although the smallest in number, $N=27$, and the Business Administration graduates, $N=888$, by far the largest in number, have slightly better promotability ratings. By inspection, the law graduates had the poorest mean ranking. However, it

\footnotetext{
${ }^{8}$ For example, see "Industry and Liberal Arts," Saturday Review of Literature (November, 1953), pp. 32-46.

'See Pierson, op. cit., and Robert Gordon and James Howell, Higher Education for Business (Now York: Columbia University Press, 1959).
} 


\section{TABLE 3}

Mean Promotability Ratings* For Educational Subject. Majors

\begin{tabular}{lrcc}
\hline Academic Major & No. & $\begin{array}{c}\text { Mean Promotability } \\
\text { Rating } \\
\text { high; } 4, \text { low })\end{array}$ & $\begin{array}{c}\text { Standard } \\
\text { Deviation }\end{array}$ \\
\hline Liberal Arts & 267 & 2.31 & .95 \\
Business Administration & 888 & 2.22 & .94 \\
Law & 41 & 2.46 & 1.21 \\
Life and Earth Science & 27 & 2.15 & .86 \\
Technical Sclences & 119 & 2.34 & .99 \\
Engineering & 242 & 2.29 & 1.13 \\
\hline
\end{tabular}

"A No. 1 ranking stands for immediately promotable; No. 2, within two years; No. 3, within two to five years; and No. 4, nonpromotable.

should be added that the law and engineering majors had the largest standard deviations, indicating a wider range of talent in these two groups. When a statistical test of differences between means was calculated, it was found that there were no significant differences between any of the educational majors.

This result is supported by an earlier study conducted on over 10,000 college graduates employed in the Bell System.10 In analyzing the relationship between relative salary progress and college major, they found 32 per cent of arts and sciences majors, 31 per cent of the business majors, and 34 per cent of the engineering majors fell in the top third salary range. The Bell study concluded that only scholastic achievement (rank in graduating class) was a substantial predictor of progress in management. The quality of the college and extracurricular activities had some effect, but working his way through school and the academic major had no effect on future managerial success in the Bell System.

As in the Bell study, no relationship was found in this study between a person's type of education and his promotability rating. In other words, a man's educational major seemed to have little, if any, effect on his later job success in the marketing department of this organization.

\section{SUMMARY AND CONCLUSIONS}

This study attempts to move one step closer to empirical validation of management education. Many organizations are becoming increasingly concerned with their attitudes and policies regarding the formal and developmental educations of their personnel. Both scholars and practitioners generally have formed definite opinions about the overall college educational experience and the specific type of education that will lead to future management success. On the other hand, research has not pro-

${ }^{10}$ Reported in "From the World of College to the World of Work," a lecture given by Frederick R. Kappel on April 5, 1962. Reprint supplied by the American Telephone and Telegraph Company. 
vided many answers or even much insight into the matter. This study at least gives insights into the better understanding of the effects that formal education has on later management success.

There were two major findings. First, managers who were considered to be promotable (either immediately or potentially) had more formal education than those felt to be nonpromotable. However, a more detailed analysis revealed the complexity of this relationship. When the data were reclassified, it was found that those viewed as having potential promotability in the company actually had more formal education than those judged immediately ready for advancement. Factors such as age and performance were found to play an important role in differentiating between the immediately and potentially promotable managers. However, the conclusion is that the formal educational experience has a definite, if somewhat complex, impact on management success.

The second major finding was much clearer. There was found to be no significant relationship between an individual's academic major and his promotability rating. Coupled with the first finding, the overall conclusion is that to be successful in the marketing department of this company, one should have a college degree, but the area of specialization has no effect. This conclusion implies more emphasis on individuality rather than on a common specialized formal education. Another implication may be that the college degree is a self-validating criterion for executive success, but the academic major is not as important in the eyes of superiors. In other words, when a superior judges a subordinate to be immediately promotable or perceives a man as being potentially promotable, one of the main determinants that enters into the decision or perception is whether or not he has a college degree, but not necessarily what educational major.

The future of management education seems certain. Organizations will continue to give emphasis to the educational background of their personnel. It is hoped they will also question its validity. This study has taken the necessary first step in the long road toward validating management education.

Leon Megginson, our man in West Pakistan, requests your cooperation in assisting the Institute of Business Administration in West Pakistan in developing its library. If you have copies of current texts, in good condition, which you care to donate please send them to:

DR. LEON MEGGINSON

Ford Foundation

P. O. Box 7282

KARACHI, 3, West Pakistan 